\title{
Dietary overlap and partitioning among three sympatric carcharhinid sharks
}

\author{
Bree J. Tillett ${ }^{1,2,3, *}$, Mark G. Meekan ${ }^{2,4}$, Iain C. Field ${ }^{1,2,5}$ \\ ${ }^{1}$ Research Institute for the Environment and Livelihoods, Charles Darwin University, Casuarina, Northern Territory 0810 , \\ Australia \\ ${ }^{2}$ Australian Institute of Marine Science, Arafura Timor Research Facility, Casuarina, Northern Territory 0810, Australia \\ ${ }^{3}$ Tropical Rivers and Coastal Knowledge Research Hub, Charles Darwin University, Casuarina, Northern Territory 0810, \\ Australia \\ ${ }^{4}$ Australian Institute of Marine Science, UWA Oceans Institute (MO 96), 35 Stirling Highway, Crawley, \\ Western Australia 6009, Australia \\ ${ }^{5}$ Graduate School of the Environment, Macquarie University, Sydney, New South Wales 2109, Australia
}

\begin{abstract}
We used stomach content and stable isotope analyses to compare diet as a proxy for ecological similarity among 3 tropical sharks, Carcharhinus leucas, C. amboinensis and the Endangered Glyphis spp. Our analyses suggested that all 3 predators consumed mainly teleost fishes but also preyed on crustaceans, cephalopods and reptiles. Diets varied spatially and through ontogeny. Some juvenile $C$. leucas sourced prey from the same food web as juvenile $C$. amboinensis, although prey sources varied among C. leucas nurseries. Dietary overlap existed between sympatric adult $C$. leucas and $C$. amboinensis, and both species occupied higher trophic positions than juvenile conspecifics. Although sample sizes for Glyphis spp. were small, our results suggested previously undescribed dietary partitioning between this genus and the sympatric C. leucas.
\end{abstract}

KEY WORDS: Niche $\cdot$ Co-existence $\cdot$ Carcharhinus spp. Sharks $\cdot$ North Australia Resale or republication not permitted without written consent of the publisher

\section{INTRODUCTION}

As top-order predators, sharks are thought to have a major role in structuring energy flows and trophic ecologies of the ecosystems in which they occur (Heithaus et al. 2008). The shallow, coastal environments of the tropics are characterized by high species diversity of carcharhinid sharks, many of which appear morphologically very similar (Speed et al. 2012). Whether this superficial appearance of similarity does indeed reflect an equivalence of trophic roles is largely unknown and may have important implications for resilience of these ecosystems, due to increasing human impacts on shark populations both directly through fisheries and indirectly through phenomena such as global warming and habitat loss
(Stevens et al. 2000, Stevens 2002, Salini et al. 2007, IUCN 2010).

Trophic interactions that are associated with ecological function are one tool for comparing ecological similarity among species (Bruno \& O'Connor 2005, Griffin et al. 2008).Typically, these can be quantified by stomach content and stable isotope analyses (Estrada et al. 2003, Bethea et al. 2004, Domi et al. 2005, Maia et al. 2006). The former provides a 'snapshot' of recently ingested prey, allowing identification and in some cases other additional biological information (e.g. sex, size, age) of prey, but such analyses are limited by stomach size and evacuation rate (Hyslop 1980, Cortes 1997). Stable isotope analyses overcome these problems as prey are identified from chemical signatures $\left(\delta^{13} \mathrm{C}\right.$ and $\delta^{15} \mathrm{~N}$, the ratios of 
heavier to lighter isotopes of these elements; ${ }^{13} \mathrm{C}:{ }^{12} \mathrm{C}$; ${ }^{15} \mathrm{~N}:{ }^{14} \mathrm{~N}$ ) assimilated into tissue, thus providing a long-term record of digested prey (Logan \& Lutcavage 2010). As these isotopes move through the food web, the ratio of heavier to lighter isotopes shifts (fragmentation), changing the predator's isotopic value to that of its prey, with a slight enrichment (Post 2002). As $\delta^{13} \mathrm{C}$ isotopes remain relatively unchanged they serve as a good indicator of prey source, whereas $\delta^{15} \mathrm{~N}$ isotopes enrich at $3.4 \%$ per trophic level, enabling calculation of trophic position of the study animal (Peterson \& Fry 1987, Estrada et al. 2005).

Here, stable isotope and stomach content analyses are used to examine trophic similarity of 3 sharks that inhabit tropical estuarine and freshwater ecosystems: the bull shark Carcharhinus leucas Valenciennes, 1839; pigeye shark C. amboinensis Müller \& Henle, 1839; and river sharks Glyphis spp. Müller \& Henle, 1839. Bull and pigeye sharks are both described as having a short, broad and blunt snout, small eyes, no inter-dorsal ridge and triangular saw-edged teeth (Compagno 1984, Cliff \& Dudley 1991a,b). Furthermore, both sharks are common in shallow coastal tropical and sub-tropical waters (Last \& Stevens 2009). This morphological similarity combined with overlapping distributions has led to common misidentifications and the assumption of ecological similarity (Cliff \& Dudley 1991a), although evidence for complex patterns of habitat use is beginning to question whether these 2 species are truly ecologically similar (Brunnschweiler et al. 2010, Carlson et al. 2010, Karl et al. 2011, Knip et al. 2011a,b, Tillett et al. 2012). Juvenile C. amboinensis prefer shallow coastal embayments (Knip et al. 2011a), whereas juvenile $C$. leucas inhabit freshwater nurseries (Heupel et al. 2010). As juvenile C. leucas mature, individuals increase the frequency and duration of marine excursions until they reach maturity, after which time they reside permanently in marine environments, sympatric with adult $C$. amboinensis (Simpfendorfer et al. 2005, Yeiser et al. 2008, Tillett et al. 2011b). The International Union for the Conservation of Nature (IUCN) has classified C. leucas as Near Threatened (IUCN 2010), whereas the frequent misidentifications of C. amboinensis, (mostly as C. leucas) in fishery catches have impeded estimates of population status, resulting in IUCN classification of this species as Data Deficient (IUCN 2010). Glyphis spp. also occupy freshwater nurseries, although the habitats used during the remainder of their life-cycle (i.e. duration spent in freshwater and habitat changes post-maturity) are unclear (Stevens et al. 2005, Last \&
Stevens 2009). The lack of sound biological data and the exploitation of many populations across the range of this species have contributed to its classification as Endangered (IUCN 2010).

Northern Australia is considered one of the last population strongholds for Glyphis spp. (Taniuchi et al. 1991), and stocks of both Carcharhinus leucas and C. amboinensis in this region are also less impacted by human activity than in most other parts of the species' ranges (Field et al. 2009). As such, northern Australia provides one of the few places where trophic partitioning among these sharks can be studied without the strong confounding effects of anthropogenic influences such as fishing and habitat degradation.

This study assesses dietary similarity by determining (1) the degree of long-term dietary overlap between Carcharhinus leucas and C. amboinensis; (2) whether prey identity and the number of prey species consumed differs between juvenile $C$. leucas and C. amboinensis; (3) whether prey identity and number increases with maturity of $C$. amboinensis; (4) whether any increase in prey diversity correlates with adults occupying higher trophic positions and whether this differs between C. leucas and $C$. amboinensis (Werry et al. 2011, Hussey et al. 2011) and; (5) whether any dietary differences are further partitioned by gender. Lastly, (6) we provide preliminary dietary analysis for endangered Glyphis spp.

\section{MATERIALS AND METHODS}

\section{Sample collection}

Samples were collected by observers working with the Northern Territory Offshore Net and Line (NTONL) and Barramundi fisheries (NTBarr) operating along the Northern Territory (Australia) coastline in 2009 and by fishery-independent surveys conducted in Van Diemen Gulf, Daly River and Darwin Harbour from 2009 to 2010 (Fig. 1). Stomachs were removed from 48 (43 juvenile and 5 adult) Carcharhinus leucas. Juveniles were collected from Blue Mud Bay $(\mathrm{n}=5)$, Van Diemen Gulf $(\mathrm{n}=15)$, Daly River ( $\mathrm{n}$ = 15), and oceanic locations $(\mathrm{n}=8)$. All adult $C$. leucas were collected north of the Tiwi Islands. Stomachs were also removed from 106 (79 juvenile and 27 adult) $C$. amboinensis. Juvenile $C$. amboinensis were collected from Darwin Harbour $(\mathrm{n}=30)$, Fog Bay ( $\mathrm{n}=$ 41 ) and oceanic locations $(n=8)$. Similar to adult $C$. leucas, all adult $C$. amboinensis were collected north of the Tiwi Islands. Five juvenile Glyphis spp. sharks 


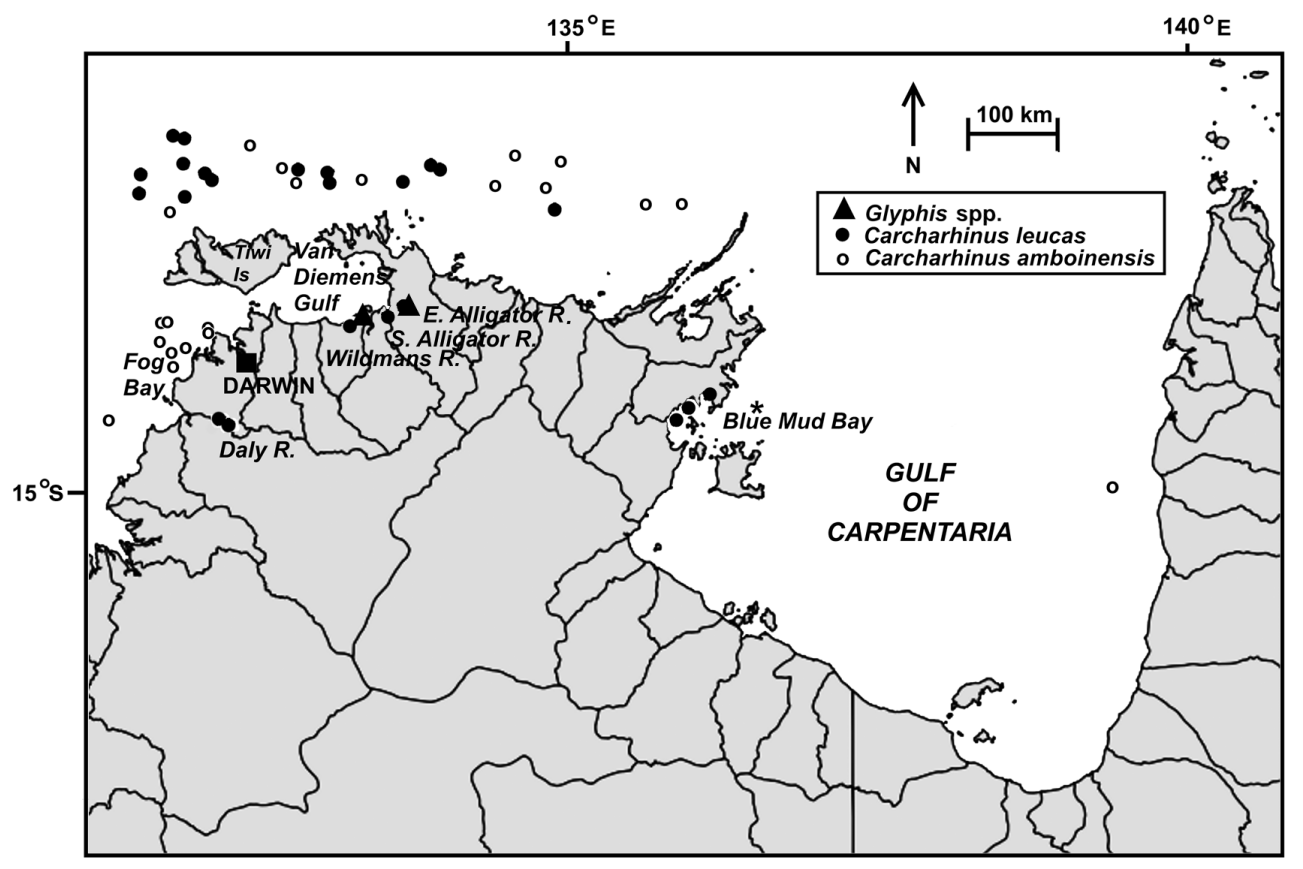

Fig. 1. Capture locations for pigeye sharks Carcharhinus amboinensis $(\mathrm{n}=106 ; 79$ juvenile and 27 adult), bull sharks $C$. leucas ( $\mathrm{n}=48 ; 43$ juvenile and 5 adult) and northern river sharks Glyphis spp. ( $\mathrm{n}=5 ; 5$ juvenile and 0 adults) across northern Australia

were also collected from Van Diemen Gulf. All stomachs were stored frozen. In addition, 10 to 15 thoracic vertebrae were removed for stable isotope analyses from a subsample of juvenile $C$. leucas resident in the Daly River $(\mathrm{n}=15)$ and Van Diemen Gulf $(\mathrm{n}=20)$ freshwater nurseries, adult $C$. leucas $(\mathrm{n}=20)$ occupying oceanic regions, juvenile and adult $C$. amboinensis ( $\mathrm{n}=20$ for both cohorts) residing in Fog Bay and oceanic regions, respectively, and juvenile Glyphis spp. occupying the East Alligator River $(n=5)$; these were stored frozen. Maturity was determined from previously described age structure and growth dynamic assessments (Tillett et al. 2011a). Sex, total weight (TW) total length (TL) and fork length (FL) were collected when possible from dead specimens. Small individuals $(<1 \mathrm{~m} \mathrm{TL})$ were inspected for the presence of umbilical scars as an indication of time since birth.

\section{Stomach content analyses}

Once thawed, stomach contents were flushed with freshwater and placed on a sorting tray. Prey contents including hard structures such as otoliths, skulls, vertebrae and stingray barbs were identified to the finest taxonomic resolution possible. Contents with shear cuts associated with filleting such as directly behind the skull at the base on the vertebral column were identified as fishery discards. Frequency of occurrence was determined as the proportion of each species identified relative to the total number of identified species.

Prey species accumulation curves were calculated for C. leucas and C. amboinensis based on random addition of individuals and 1000 permutations. No statistical analyses were performed on gut samples of Glyphis spp. or between adult C. leucas and C. amboinensis due to low sample sizes. Broad differences between prey taxa consumed by (1) juvenile C. leucas and C. amboinensis, (2) juvenile and adult C. amboinensis and (3) between genders were compared using permutational multivariate analysis of variance, PERMANOVA (presence/absence data) on Bray-Curtis similarity matrices (PRIMER-6, Plymouth Marine Laboratory, PML) using 9999 permutations. To overcome low sample sizes, p-values based on unrestricted permutations of raw data and Monte Carlo sampling were compared. Where significant differences between main effects were identified, similarity of percentages analyses, SIMPER (PRIMER-6, PML) described which prey taxa differed between groups (presence/absence). Additionally, ANOVA and generalised linear modelling (GLM) was applied in R cran (R Development Core Team 2011) to determine any finer-scale differences in the number of prey species consumed among the above groups. Akaike's information criterion cor- 
rected for small sample size $\left(\mathrm{AIC}_{\mathrm{c}}\right)$ ranked models based on their bias-corrected distance from the true model (Burnham \& Anderson 2002, Link \& Barker 2006). Here, the relative weight of evidence for each model given the model set was its $\mathrm{AIC}_{\mathrm{c}}$ weight $\left(w A I C_{c}\right)$ ranging from 0 (no support) to 1 (complete support) (Burnham \& Anderson 2002). Each model's goodness of fit was also estimated using the percentage of deviance explained (\%DE) relative to the null (intercept-only) model. For consistency, within these analyses unknown prey types such as teleosts that could not be identified were classified as separate species within taxa, e.g. as unknown teleosts. Standard Shannon-Wiener diversity indices were also calculated between juvenile $C$. leucas and $C$. amboinensis and also between juvenile and adult $C$. amboinensis.

\section{Stable isotope analyses}

Frozen vertebrae of sharks were defrosted prior to stable isotope analyses and excess tissue, neural and haemal arches were excised to expose the centra. Individual centra were separated and any connective tissue removed by washing in Milli-Q water. Polished centra were left to air-dry causing any remaining tissue to become brittle and peel away. To ensure only diet post-parturition was analysed, cores of juvenile vertebrae corresponding to in vitro development (post the angle of change) were removed and the remaining material was ground and oven dried $(\sim 0.8 \mathrm{mg})$. Adult vertebrae were sectioned $(\sim 2 \mathrm{~mm})$ using a low-speed isomet diamond saw at approximately $240 \mathrm{rpm}$ with a $250 \mathrm{~g}$ load weight. Potential contaminants were removed by grinding sections on wet and dry paper and rinsing again in Milli-Q water. Sections were viewed under a Leica DM 400B compound microscope, and the outer growth band representing the final year before capture was removed, ground and oven dried $(\sim 0.8 \mathrm{mg})$. Samples were then combusted in an EA 3000 elemental analyser (Eurovector) and sample gases delivered to an Isoprime mass spectrometer (GV Instruments) for isotope analysis of $\mathrm{C}$ and $\mathrm{N}$. Working standards were liquids calibrated against IAEA CH6, CH7, N1 and N2, and had elemental composition that matched the samples $(44 \% \mathrm{C}$ and $11 \%$ $\mathrm{N})$. Average $\delta^{13} \mathrm{C}$ values for sharks were plotted against average $\delta^{15} \mathrm{~N}$ values and compared between age cohorts, species and habitats. Layman metrics were also calculated using the SIAR package in $\mathrm{R}$ cran (R Development Core Team 2011) and compared between shark species and maturity stages (Layman

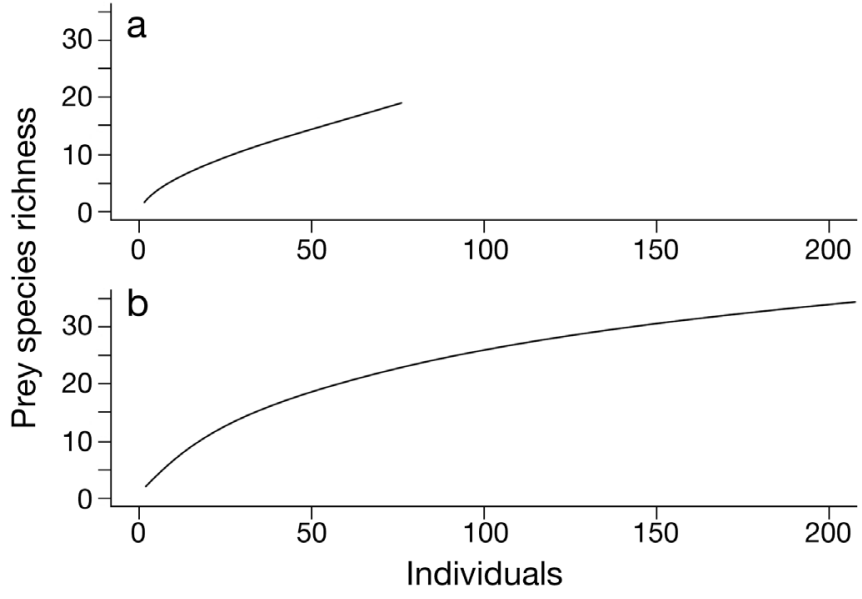

Fig. 2. Prey species accumulation curves for (a) Carcharhinus leucas $(\mathrm{n}=48)$ and $(\mathrm{b}) C$. amboinensis $(\mathrm{n}=106)$ based on random addition of individuals and 1000 permutations

et al. 2007). Limited sample sizes prevented further comparisons between juvenile $C$. leucas and $C$. amboinensis or between juvenile $C$. leucas nurseries.

\section{RESULTS}

\section{Stomach content analyses}

An asymptote in the prey species accumulation curve indicated that increasing the sample size of stomachs of Carcharhinus amboinensis would have been unlikely to identify many new prey species. However, an obvious asymptote did not occur for $C$. leucas suggesting that we under-sampled the range of prey of this species (Fig. 2). Analysis of stomach contents showed that $C$. leucas and C. amboinensis fed on a diverse array of prey taxa (Fig 3, Table 1). Both juvenile C. leucas and C. amboinensis ate crustaceans, other elasmobranchs and teleost fish (Table 2); however, the diet of C. amboinensis also included cephalopods and a wider range of teleost fishes than found in the stomachs of C. leucas (Table 3). Debris (e.g. rocks, sand, leaves) were common in C. leucas stomachs and both this species and C. amboinensis consumed fishery discards, although these were more common in the stomachs of the latter species (Table 3). Prey taxa i.e. crustaceans, teleosts etc. consumed by juvenile and adult $C$. amboinensis did not differ (Table 2); however, significant differences in the number of prey species were identified ( $\mathrm{p}=0.012$; ANOVA). Juvenile C. amboinensis fed on a greater proportion of crustaceans and had fewer empty stomachs than adults (Fig. 3, 
Table 1), although the prey taxa did not differ between genders of this species (Table 2). The number of prey species also differed between juvenile C. leucas and $C$. amboinensis $(\mathrm{p}=$ 0.0001 ; ANOVA) and between juvenile and adult $C$. amboinensis ( $\mathrm{p}=$ 0.012 ; ANOVA), although again, not between genders $(p=0.880$; ANOVA and $\mathrm{p}=0.639$; ANOVA respectively for each group). Generalised linear models supported these results (Table 4). Interestingly, although sample sizes were small, only teleosts were found in the guts of Glyphis spp. Shannon-Wiener diversity indices for C. amboinensis and C. leucas were 2.625 and 2.076 respectively, and 2.660 and 2.227 for juvenile and mature $C$. amboinensis respectively.

\section{Stable isotope analyses}

Mean values of $\delta^{15} \mathrm{~N}$ were higher for adults than juveniles of both $C$. leucas and $C$. amboinensis. Conversely, mean values of $\delta^{13} \mathrm{C}$ were similar between juveniles and adults within species. Mean $\delta^{13} \mathrm{C}$ values were also similar for juvenile $C$. leucas and $C$. amboinensis, despite the former inhabiting freshwater and the latter occupying estuarine nurseries. However, mean $\delta^{13} \mathrm{C}$ values differed for juvenile $C$. leucas among freshwater nurseries and between juvenile C. leucas and Glyphis spp. that occupied the same nurseries. Juvenile $C$. leucas had the broadest range of mean $\delta^{13} \mathrm{C}$ values (Fig. 4). C. leucas occupied the widest niche space with the most diversity present in juveniles. Conversely, trophic diversity of juvenile and adult $C$. amboinensis was similar (Table 5).

\section{DISCUSSION}

Our results confirm the diversities of intra- and inter-specific ecologies in coastal sharks. Juvenile Carcharhinus leucas and C. amboinensis, much like other coastal carcharhinids, fed on a wide selection of prey, consuming mostly teleosts, but also cephalopods, crustaceans and reptiles (Salini et al. 1992,
Bethea et al. 2004, McElroy et al. 2006, Last \& Stevens 2009, Newman et al. 2010). Stomach content analyses of $C$. leucas collected from south-east Queensland and north-west Australian estuaries have reported similar diets for this species (Stevens \& McLoughlin 1991, Thorburn \& Rowland 2008, Werry et al. 2011). Stomach content analysis of Glyphis spp. identified a diet solely composed of teleosts. However, the breadth of $\delta^{13} \mathrm{C}$ values in tissues, which provide a long-term record of digested prey, indicated a broader diet, possibly from a different food web than either juvenile $C$. leucas or $C$. amboinensis. This comparison must be treated with caution, since only 5 individuals of Glyphis spp. were sampled. Such dietary variation displayed in these 3 species is commonly associated with 'generalist predators' (Ellis \& Musick 2007, Lopez et al. 2009); however, recent research has shown that for $C$. leucas, despite a 
Table 1. Percent frequency of occurrence (\% FO) of prey items in stomach contents for bull sharks Carcharhinus leucas, pigeye sharks C. amboinensis and northern river sharks Glyphis spp. All prey items were identified to the lowest possible classification; $\mathrm{n}=$ number of stomachs containing prey item; empty: no prey items found $C$

\begin{tabular}{|c|c|c|c|c|c|c|}
\hline \multirow[t]{2}{*}{ Prey item } & \multicolumn{2}{|c|}{ C. leucas $(\mathrm{n}=48)$} & \multicolumn{2}{|c|}{ C. amboinensis $(\mathrm{n}=106)$} & \multicolumn{2}{|c|}{ Glyphis spp. $(\mathrm{n}=5$} \\
\hline & $\% \mathrm{FO}$ & $\mathrm{n}$ & $\% \mathrm{FO}$ & $\mathrm{n}$ & $\% \mathrm{FO}$ & $\mathrm{n}$ \\
\hline \multicolumn{7}{|l|}{ Crustaceans } \\
\hline Unknown order & 2.08 & 1 & - & - & - & - \\
\hline Stomatopoda & - & - & & & - & - \\
\hline Squillidae & - & - & 2.83 & 3 & - & - \\
\hline Decapoda unknown family & 12.50 & 6 & 2.83 & 3 & - & - \\
\hline Palaemonidae unknown genera & 10.42 & 5 & - & - & - & - \\
\hline Macrobrachium rosenbergii & 2.08 & 1 & - & - & - & - \\
\hline Penaeidae & - & - & & & - & - \\
\hline Penaeus spp. & - & - & 8.49 & 9 & - & - \\
\hline Copepoda & 4.17 & 2 & 8.49 & 9 & - & - \\
\hline \multicolumn{7}{|l|}{ Cephalopods } \\
\hline Unknown order & - & - & 11.32 & 12 & - & - \\
\hline Teuthida & - & - & & & - & - \\
\hline Loliginidae & - & - & 0.94 & 1 & - & - \\
\hline Ommastrephidae & - & - & 0.94 & 1 & - & - \\
\hline Sepiolida & - & - & & & - & - \\
\hline Sepiolidae unknown genera & - & - & 2.83 & 3 & - & - \\
\hline Sepia spp. & - & - & 5.66 & 6 & - & - \\
\hline Octopoda & - & - & 0.94 & 1 & - & - \\
\hline \multicolumn{7}{|l|}{ Elasmobranchs } \\
\hline Unknown order & 2.08 & 1 & 10.38 & 11 & - & - \\
\hline Carcharhiniformes & & & & & - & - \\
\hline Carcharhinidae & 2.08 & 1 & 1.89 & 2 & - & - \\
\hline Myliobatiformes & & & & & - & - \\
\hline Dasyatidae & 2.08 & 1 & 1.89 & 2 & - & - \\
\hline \multicolumn{7}{|l|}{ Teleost fishes } \\
\hline Perciformes unknown family & 62.50 & 30 & 76.42 & 81 & 60 & 3 \\
\hline Acanthuridae & - & - & 0.94 & 1 & - & - \\
\hline Carangidae & 2.08 & 1 & 4.72 & 5 & - & - \\
\hline Centropomidae & 4.17 & 2 & - & - & - & - \\
\hline Gobiidae & 2.08 & 1 & 2.83 & 3 & - & - \\
\hline Teraponidae & - & - & 3.77 & 4 & - & - \\
\hline Labridae & - & - & 0.94 & 1 & - & - \\
\hline Polynemidae & - & - & 0.94 & 1 & - & - \\
\hline Pomacanthidae & - & - & 0.94 & 1 & - & - \\
\hline Scombridae & 2.08 & 1 & 2.83 & 3 & - & - \\
\hline Sparidae & - & - & 0.94 & 1 & - & - \\
\hline Ambassidae & & & - & - & - & - \\
\hline Ambassis sp. & 2.08 & 1 & - & - & - & - \\
\hline \multicolumn{7}{|l|}{ Ariidae } \\
\hline Arius sp. & 10.42 & 5 & 0.94 & 1 & 40 & 2 \\
\hline Leiognathidae & & & & & - & - \\
\hline Leiognathus sp. & 2.08 & 1 & 9.43 & 10 & - & - \\
\hline Psettodidae & - & - & & & - & - \\
\hline Psettodes sp. & - & - & 0.94 & 1 & - & - \\
\hline Sciaenidae & - & - & & & - & - \\
\hline Austroneba sp. & - & - & 5.66 & 6 & - & - \\
\hline Johinus sp. & - & - & 7.55 & 8 & - & - \\
\hline Nibea sp. & - & - & 1.89 & 2 & 40 & 2 \\
\hline Otolithes sp. & - & - & 4.72 & 5 & - & - \\
\hline Clupeiformes & - & - & & & - & - \\
\hline Chirocentridae & - & - & 0.94 & 1 & - & - \\
\hline Elopiformes & - & - & & & - & - \\
\hline Megalopidae & - & - & 0.94 & 1 & - & - \\
\hline Synbranchiformes & & & - & - & - & - \\
\hline Synbranchidae & 2.08 & 1 & - & - & - & - \\
\hline Tetraodontiformes & - & - & & & - & - \\
\hline Tetraodontidae & - & - & 0.94 & 1 & - & - \\
\hline
\end{tabular}


Table 1 (continued)

\begin{tabular}{|c|c|c|c|c|c|c|}
\hline \multirow[t]{2}{*}{ Prey item } & \multicolumn{2}{|c|}{ C. leucas $(\mathrm{n}=48)$} & \multicolumn{2}{|c|}{ C. amboinensis $(\mathrm{n}=106)$} & \multicolumn{2}{|c|}{ Glyphis spp. $(\mathrm{n}=5)$} \\
\hline & $\% \mathrm{FO}$ & $\mathrm{n}$ & $\% \mathrm{FO}$ & $\mathrm{n}$ & $\% \mathrm{FO}$ & $\mathrm{n}$ \\
\hline Anguilliformes & & & - & - & & \\
\hline Anguillidae & & - & - & & & \\
\hline Anguilla sp. & 2.08 & 1 & - & - & 20 & 1 \\
\hline Osteoglossiformes & & & & & & \\
\hline Osteoglossidae & & & - & - & - & - \\
\hline Scleropages sp. & 2.08 & 1 & - & - & - & - \\
\hline Reptiles & & & & & & \\
\hline Squamata & & & & & & \\
\hline Elapidae & - & - & & & - & - \\
\hline Aipysurus sp. & - & - & 1.89 & 2 & - & - \\
\hline Fishery discards & 2.08 & 1 & 14.15 & 15 & - & - \\
\hline Debris & 37.50 & 18 & 9.43 & 10 & - & - \\
\hline Empty & 16.67 & 8 & 13.21 & 14 & - & - \\
\hline
\end{tabular}

Table 2. Permutational multivariate analysis of variance, PERMANOVA (presence/absence data) on Bray-Curtis similarity matrices using 9999 permutations. (a) Differences in prey taxa between juvenile Carcharhinus leucas (n = 43) and juvenile C. amboinensis $(\mathrm{n}=79)$; (b) differences in prey taxa consumed between juvenile $(\mathrm{n}=79)$ and adult $C$. amboinensis $(\mathrm{n}=27)$. df: degrees of freedom; SS: sum of squared error; MS: mean of squared error; $\alpha=0.05$; N: number of unique permutations. Significant $\mathrm{p}$-values are in bold

\begin{tabular}{|c|c|c|c|c|c|c|c|c|}
\hline & Source & $\mathrm{df}$ & SS & MS & Pseudo- $F$ & p (Permutation) & $\mathrm{N}$ & p (Monte Carlo) \\
\hline \multirow[t]{3}{*}{ a) } & Species & 1 & 11416 & 11416 & 13.32 & 0.083 & 12 & 0.034 \\
\hline & Sex & 1 & 1820.7 & 1820.7 & 2.20 & 0.331 & 12 & 0.259 \\
\hline & Species $\times$ Sex & 1 & 839.98 & 839.98 & 0.43 & 0.745 & 9954 & 0.731 \\
\hline \multirow[t]{3}{*}{ b) } & Maturity & 1 & 6689.1 & 6689.1 & 5.84 & 0.257 & 412 & 0.084 \\
\hline & Sex & 1 & 1131 & 1131 & 1.36 & 0.494 & 12 & 0.435 \\
\hline & Sex $\times$ Maturity & 1 & 1136.4 & 1136.4 & 0.52 & 0.666 & 9960 & 0.662 \\
\hline
\end{tabular}

Table 3. Similarity of percentage (SIMPER) analyses between juvenile Carcharhinus leucas $(\mathrm{n}=43)$ and pigeye $C$. amboinensis $(\mathrm{n}=79)$ sharks

\begin{tabular}{|c|c|c|c|c|c|c|}
\hline \multirow[t]{2}{*}{ Prey type } & \multicolumn{2}{|c|}{ Mean abundance } & \multicolumn{2}{|c|}{ Dissimilarity } & \multirow{2}{*}{$\begin{array}{c}\% \\
\text { contri- } \\
\text { bution }\end{array}$} & \multirow{2}{*}{$\begin{array}{c}\% \\
\text { cumu- } \\
\text { lation }\end{array}$} \\
\hline & $\begin{array}{c}C . \\
\text { leucas }\end{array}$ & $\begin{array}{l}\text { C. ambo- } \\
\text { inensis }\end{array}$ & Mean & $\mathrm{SD}$ & & \\
\hline Teleost & 0.79 & 0.81 & 12.06 & 0.64 & 22.72 & 22.72 \\
\hline Debri & 0.42 & 0.05 & 11.87 & 0.81 & 22.36 & 45.08 \\
\hline Crustacean & 0.26 & 0.18 & 9.38 & 0.68 & 17.67 & 62.75 \\
\hline Empty & 0.12 & 0.09 & 7.44 & 0.45 & 14.01 & 76.76 \\
\hline Cephalopod & 0.00 & 0.16 & 4.64 & 0.41 & 8.74 & 85.50 \\
\hline Fishery discards & 0.00 & 0.15 & 3.87 & 0.41 & 7.29 & 92.79 \\
\hline
\end{tabular}

broad diet for the species as a whole, the diet of each individual is less varied, suggesting that the species are individual dietary specialists, rather than true generalists (Matich et al. 2011).

Competition for prey (indicated by the degree of $\delta^{13} \mathrm{C}$ overlap) between $C$. leucas and C. amboinensis should increase through ontogeny because these species move from separate nurseries to shared adult habitat (Compagno 1984). However, $\delta^{13} \mathrm{C}$ results from the current study suggest that dietary overlap, or at least competition for prey from similar trophic levels could occur at the juvenile stage and then continue into adult life. There was also some evidence that this result was dependent on sampling location, as we found large differences in prey source (as indicated by $\delta^{13} \mathrm{C}$ values) among juveniles of $C$. leucas inhabiting different freshwater nurseries. These differences may be due to the occupation of different salinity environments within each river nursery (Heupel \& Simpendorfer 2008, Ortega et al. 2009) and relative inputs from terrestrial carbon sources (Fry \& Sherr 1984). Dietary overlap between similar-sized sharks was reported by Bethea et al. (2004) although it was hypothesized that these species may have reduced competition by partitioning resources in time or space. In our study, differences in prey taxa and species consumed by juvenile $C$. leucas and $C$. 
Table 4. Information-theoretic ranking of models testing the effects of species, sex and maturity on prey species diversity. (a) Prey species diversity between juvenile Carcharhinus leucas $(\mathrm{n}=43)$ and juvenile C. amboinensis $(\mathrm{n}=79)$; $(\mathrm{b})$ prey species diversity between juvenile $(\mathrm{n}=79)$ and adult $(\mathrm{n}=27)$ C. amboinensis. LL: maximum log-likelihood; $k$ : number of model parameters; $\mathrm{AIC}_{\mathrm{c}}$ : Akaike's information criterion corrected for small samples; $\Delta \mathrm{AIC}_{\mathrm{c}}$ : differences between the current and top-ranked model $\mathrm{AIC}_{\mathrm{c} i}$ WAIC $_{\mathrm{c}}$ : $\mathrm{AIC}_{\mathrm{c}}$ weights; \% DE: percent deviance explained

\begin{tabular}{|c|c|c|c|c|c|c|c|}
\hline & Model & LL & $k$ & $\mathrm{AIC}_{\mathrm{c}}$ & $\Delta \mathrm{AIC}_{\mathrm{c}}$ & $w \mathrm{AIC}_{\mathrm{c}}$ & $\% \mathrm{DE}$ \\
\hline \multirow[t]{4}{*}{ a) } & Diversity $\sim$ Species & -186.67 & 2 & 377.44 & 0.00 & 0.668 & 11.23 \\
\hline & Diversity $\sim$ Sex & -197.91 & 2 & 389.93 & 12.48 & 0.001 & 0.13 \\
\hline & Diversity $\sim$ Species + Sex & -186.66 & 3 & 379.52 & 2.09 & 0.235 & 11.25 \\
\hline & Diversity $\sim$ Species $\times$ Sex & -186.49 & 4 & 381.33 & 3.89 & 0.096 & 11.55 \\
\hline \multirow[t]{4}{*}{ b) } & Diversity Maturity & -169.44 & 2 & 342.99 & 0.00 & 0.625 & 5.22 \\
\hline & Diversity $\sim$ Sex & -172.10 & 2 & 348.31 & 5.31 & 0.044 & 0.16 \\
\hline & Diversity $\sim$ Sex + Maturity & -169.31 & 3 & 344.86 & 1.86 & 0.246 & 5.46 \\
\hline & Diversity $\sim$ Sex $\times$ Maturity & -169.29 & 4 & 346.99 & 3.99 & 0.085 & 5.48 \\
\hline
\end{tabular}

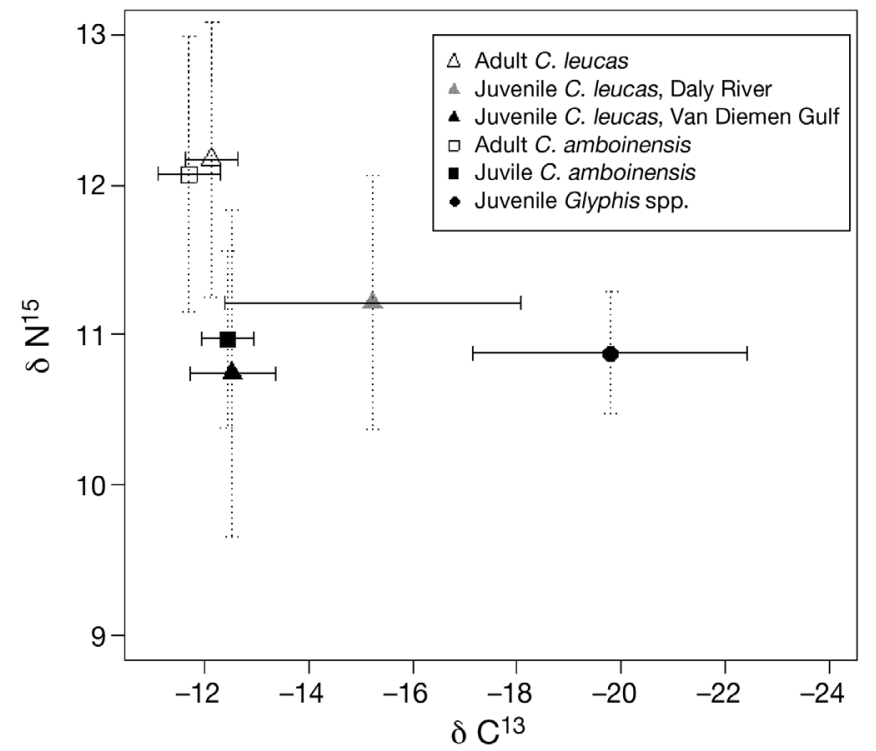

Fig. 4. Mean and variation of vertebral $\delta^{13} \mathrm{C}$ and $\delta^{15} \mathrm{~N}$ concentrations from adult bull sharks Carcharhinus leucas $(\mathrm{n}=20)$, adult pigeye sharks $C$. amboinensis $(\mathrm{n}=20)$, juvenile bull sharks (sampled from 2 nurseries; $\mathrm{n}=15$ and $\mathrm{n}=20$ for Daly River and Van Diemen Gulf, respectively), juvenile pigeye sharks $(n=20)$, and juvenile northern river sharks Glyphis spp. (n=5) amboinensis identified from stomach contents could indicate temporal or spatial partitioning of diet within these food webs although it is unclear if this also occurs between sympatric adults.

We also found significant differences in diet between juvenile and adult C. amboinensis. Changes in diet with maturity are common in sharks, probably reflecting the improved foraging experience and prey acquisition skills of adults relative to juveniles (Lowe et al. 1996, Estrada et al. 2006, McElroy et al. 2006, Estupinan-Montano et al. 2009). Adults are more likely to overcome defences of prey than juveniles and have a larger mouth gape, increasing the size and diversity of prey available (Pyke 1984). We found evidence for increased consumption of largersized (and typically higher trophic-order) prey with maturity as isotope analyses suggested that adult $C$. leucas and $C$. amboinensis occupied a higher trophic position than juveniles of the same species, similar to results reported for C. leucas in earlier work by Werry et al. (2011). Furthermore, the diversity of prey also increased with maturity in C. amboinensis.

The apparent similarities in diet we found between male and female $C$. leucas and $C$. amboinensis were

Table 5. Summary of isotopic metrics. n: total number of individuals sampled; TA: total niche space occupied; CD: mean distance to centroid; MNND: mean nearest neighbour distance; SDNND: standard deviation of nearest neighbour distance

\begin{tabular}{|lccccccc|}
\hline & $\mathrm{n}$ & $\delta^{15} \mathrm{~N}$ range & $\delta^{13}$ C range & TA & CD & MNND & SDNND \\
\hline Carcharhinus leucas & 55 & 9.8 & 5.9 & 28.74 & 1.843 & 0.353 & 0.329 \\
Carcharhinus amboinensis & 40 & 2.3 & 4.2 & 6.05 & 0.990 & 0.252 & 0.155 \\
Glyphis spp. & 5 & 5.6 & 1.1 & 2.6 & 2.255 & 0.803 & 0.285 \\
Juvenile C. leucas & 35 & 9.3 & 3.9 & 22.87 & 2.119 & 0.445 & 0.305 \\
Adult C. leucas & 20 & 2.5 & 4.3 & 5.34 & 1.034 & 0.411 & 0.359 \\
Juvenile C. amboinensis & 20 & 2 & 2 & 2.58 & 0.699 & 0.294 & 0.128 \\
Adult C. amboinensis & 20 & 2 & 2.8 & 3.31 & 0.829 & 0.312 & 0.214 \\
\hline
\end{tabular}


not unexpected, since few studies have recorded differences in diets between sexes in other carcharhinids (McElroy et al. 2006, Lopez et al. 2009, Cabrera-Chávez-Costa et al. 2010, Markaida \& SosaNishizaki 2010). This similarity occurred despite the sex-specific use of habitats driven by traits such as female philopatry, which has recently been identified in C. leucas (Tillett et al. 2012) or the possibility of female mate avoidance (Feldheim et al. 2001, 2004, Portnoy et al. 2010, Veríssimo et al. 2011). It would seem reasonable to assume that the greater energetic cost associated with egg production and gestation in females might result in preferences for prey yielding higher net energy profits, and thus differences in diet between males and females. Examination of this idea will require detailed quantification of the caloric value of diets of males and females during the time of mating and/or gestation.

The evidence we found for dietary partitioning within populations supports the conclusion of Matich et al. (2011) that individual specialisation may be an important feature of trophic dynamics in large marine predators. For juveniles, such small-scale partitioning may reflect differences in both anthropogenic pressures (e.g. fishing, dams or alteration of freshwater flow) and natural processes (e.g. catchment productivity) among estuarine systems. Because of the limited mobility of this life history stage, with juvenile $C$. leucas remaining in the same nursery habitats for up to 4 years, any differences in food availability driven by these processes are likely to be expressed in diets.

Our results suggest that resource partitioning occurs between the juveniles of sympatric C. leucas and endangered Glyphis spp. sharks in the Northern Territory (Peverell et al. 2006). Unlike the broad range of prey taken by juvenile C. leucas, only teleost fishes were identified in the stomachs of Glyphis spp. sharks. Although this result must be treated with caution, since it is based on a relatively small sample size, isotopic analyses also support the suggestion that juvenile C. leucas and Glyphis spp. feed on different food sources or that the food webs that support them are based on different primary producers. This result may reflect the fact that the nursery habitats shared by these species (freshwater rivers just upstream from estuaries) are very limited in spatial extent throughout much of northern Australia, thus providing strong selection for these species to partition resources.

Our study confirms the value in comparing both long-term and short-term analyses of diet to understand the ecological role of coastal sharks. Despite a similar dependence on coastal ecosystems, we found differences in diet both in the short-term and through ontogeny that suggests partitioning of resources by sharks within these habitats. As such, we caution against pooling morphologically similar species $C$. leucas and $C$. amboinensis in ecosystem assessments. Similarly, our preliminary assessment of the diet of Glyphis sharks shows that their diet differs from that of sympatric C. leucas, suggesting that their ecological role will differ, at least within the juvenile habitat. Overall, $\delta^{13} \mathrm{C}$ values reported here were similar to those quantified for other coastal sharks (Speed et al. 2012), reiterating the dependency of sharks on these near-shore environments and the importance of these habitats for conservation of these apex predators.

Acknowledgements. This study was funded by Tropical Rivers and Coastal Knowledge research hub. In-kind support was provided by Kakadu National Park and Department of Resources - Fisheries, Northern Territory. Sampling was conducted with the support of fishers, in particular, on the vessels 'James Hardy', 'Tulach Arch' and '34 Degrees South'. We thank G. Johnson, P. Caia and I. Jupp for aid in the field, R. Diocares for assistance with stable isotope analyses and C. Pelizc for assistance with stomach content analyses.

\section{LITERATURE CITED}

Bethea DM, Buckel JA, Carlson JK (2004) Foraging ecology of the early life stages of four sympatric shark species. Mar Ecol Prog Ser 268:245-264

> Brunnschweiler JM, Queiroz N, Sims DW (2010) Oceans apart? Short-term movements and behaviour of adult bull sharks Carcharhinus leucas in Atlantic and Pacific Oceans determined from pop-off satellite archival tagging. J Fish Biol 77:1343-1358

> Bruno JF, O'Connor MI (2005) Cascading effects of predator diversity and omnivory in a marine food web. Ecol Lett 8: 1048-1056

Burnham KP, Anderson DR (2002) Model selection and multimodel inference: a practical information-theoretic approach. Springer, New York, NY

ä Cabrera-Cáavez-Costa AA, Gálvan-Magaña F, EscobarSánchez O (2010) Food habits of the silky shark Carcharhinus falciformis (Müller \& Henle, 1839) off the western coast of Baja California Sur, Mexico. J Appl Ichthyol 26:499-503

Carlson JK, Ribera MM, Conrath CL, Heupel MR, Burgess GH (2010) Habitat use and movement patterns of bull sharks, Carcharhinus leucas determined using pop-up satellite archival tags. J Fish Biol 77:661-675

Cliff G, Dudley SFJ (1991a) Sharks caught in the protective gill nets off Natal, South Africa. 4. The bull shark Carcharhinus leucas Valenciennes. S Afr J Mar Sci 10: 253-270

Cliff G, Dudley J (1991b) Sharks caught in the protective nets off Natal, South Africa. 5. The Java Shark Carcharhinus amboinensis (Müller and Henle). S Afr J Mar Sci 11:443-453 
Compagno LJV (1984) FAO Species Catalogue, Vol 4, Part 2. An annotated and illustrated catalogue of shark species known to date, Part 2. Carcharhiniformes. FAO Fish Synop 125:445-496

> Cortes E (1997) A critical review of methods of studying fish feeding based on analysis of stomach contents: application to elasmobranch fishes. Can J Fish Aquat Sci 54: 726-738

> Domi N, Bouquegneau JM, Das K (2005) Feeding ecology of five commercial shark species of the Celtic Sea through stable isotope and trace metal analysis. Mar Environ Res 60:551-569

> Ellis JK, Musick JA (2007) Ontogenetic changes in the diet of the sandbar shark, Carcharhinus plumbeus, in lower Chesapeake Bay and Virginia (USA) coastal waters. Environ Biol Fishes 80:51-67

Estrada JA, Rice AN, Lutcavage ME, Skomall GB (2003) Trophic position in sharks of the north-west Atlantic Ocean using stable isotope analysis. J Mar Biol Assoc UK 83:1347-1350

Estrada JA, Lutcavage M, Thorrold SR (2005) Diet and trophic position of Atlantic bluefin tuna (Thunnus thynnus) inferred from stable carbon and nitrogen isotope analysis. Mar Biol 147:37-45

Estrada JA, Rice AN, Natanson LJ, Skomal GB (2006) Use of isotopic analysis of vertebrae in reconstructing ontogenetic feeding ecology in white sharks. Ecology 87: 829-834

Estupinan-Montano C, Cedeno-Figueroa LG, Galvan-Magana F (2009) Feeding habits of the scalloped hammerhead shark Sphyrna lewini (Griffith and Smith, 1834) (Chondrichthyes) in the Ecuadorian Pacific. Rev Biol Mar Oceanogr 44:379-386

Feldheim KA, Gruber SH, Ashley MV (2001) Multiple paternity of a lemon shark litter (Chondrichthyes: Carcharhinidae). Copeia 781-786

Feldheim KA, Gruber SH, Ashley MV (2004) Reconstruction of parental microsatellite genotypes reveals female polyandry and philopatry in the lemon shark, Negaprion brevirostris. Evolution 58:2332-2342

> Field IC, Meekan MG, Buckworth RC, Bradshaw CJA (2009) Protein mining the world's oceans: Australasia as an example of illegal expansion-and-displacement fishing. Fish Fish 10:323-328

Fry B, Sherr EB (1984) $\delta^{13} \mathrm{C}$ measurements as indicators of carbon flow in marine and freshwater ecosystems. Contrib Mar Sci 27:13-47

Griffin JN, De la Haye KL, Hawkins SJ, Thompson RC, Jenkins SR (2008) Predator diversity and ecosystem functioning: Density modifies the effect of resource partitioning. Ecol 89:298-305

Heithaus MR, Frid A, Wirsing AJ, Worm B (2008) Predicting ecological consequences of marine top predator declines. Trends Ecol Evol 23:202-210

> Heupel MR, Simpfendorfer CA (2008) Movement and distribution of young bull sharks Carcharhinus leucas in a variable estuarine environment. Aquat Biol 1:277-289

> Heupel MR, Yeiser BG, Collins AB, Ortega L, Simpfendorfer CA (2010) Long-term presence and movement patterns of juvenile bull sharks, Carcharhinus leucas, in an estuarine river system. Mar Freshw Res 61:1-10

Hussey NE, Dudley SFJ, McCarthy D, Cliff G, Fisk AT (2011) Stable isotope profiles of large marine predators: viable indicators of trophic position, diet, and movement in sharks? Can J Fish Aquat Sci 68:2029-2045
Hyslop EJ (1980) Stomach contents analysis - a review of critical methods and their application. J Fish Biol 17: 411-429

IUCN (2010) Red List of Threatened Species. Version 2010.3. www.iucnredlist.org

Karl S, Castro A, Lopez J, Charvet P, Burgess G (2011) Phylogeography and conservation of the bull shark (Carcharhinus leucas) inferred from mitochondrial and microsatellite DNA. Conserv Genet 12:371-382

Knip DM, Heupel M, Simpfendorfer CA, Tobin AJ, Moloney J (2011a) Ontogenetic shift in movement and habitat use for juvenile pigeye sharks Carcharhinus amboinensis in a tropical nearshore region. Mar Ecol Prog Ser 425: 233-246

> Knip DM, Heupel M, Simpfendorfer CA, Tobin AJ, Moloney J (2011b) Wet-season effects on the distribution of juvenile pigeye sharks, Carcharhinus amboinensis, in tropical nearshore waters. Mar Freshw Res 62:658-667

Last PR, Stevens JD (2009) Sharks and rays of Australia. CSIRO, Melbourne

Layman CA, Arrington DA, Montaña CG, Post DM (2007) Can stable isotope ratios provide for community-wide measures of tropic structure? Ecology 88:42-48

Link WA, Barker RJ (2006) Model weights and the foundations of multimodel inference. Ecology 87:2626-2635

> Logan JM, Lutcavage ME (2010) Stable isotope dynamics in elasmobranch fishes. Hydrobiologia 644:231-244

> Lopez S, Melendez R, Barria P (2009) Feeding of the shortfin mako shark Isurus oxyrinchus Rafinesque, 1810 (Lamniformes: Lamnidae) in the Southeastern Pacific. Rev Biol Mar Oceanogr 44:439-451 (in Spanish with English abstract)

> Lowe CG, Wetherbee BM, Crow GL, Tester AL (1996) Ontogenetic dietary shifts and feeding behavior of the tiger shark, Galeocerdo cuvier, in Hawaiian waters. Environ Biol Fishes 47:203-211

Maia A, Queiroz N, Correia JP, Cabral H (2006) Food habits of the shortfin mako, Isurus oxyrinchus, off the southwest coast of Portugal. Environ Biol Fishes 77:157-167

Markaida U, Sosa-Nishizaki O (2010) Food and feeding habits of the blue shark Prionace glauca caught off Ensenada, Baja California, Mexico, with a review on its feeding. J Mar Biol Assoc UK 90:977-994

- Matich P, Heithaus MR, Layman CA (2011) Contrasting patterns of individual specialization and trophic coupling in two marine apex predators. J Anim Ecol 80:294-305

> McElroy WD, Wetherbee BM, Mostello CS, Lowe CG, Crow GL, Wass RC (2006) Food habits and ontogenetic changes in the diet of the sandbar shark, Carcharhinus plumbeus, in Hawaii. Environ Biol Fishes 76:81-92

> Newman SP, Handy RD, Gruber SH (2010) Diet and prey preference of juvenile lemon sharks Negaprion brevirostris. Mar Ecol Prog Ser 398:221-234

Ortega LA, Heupel MR, Van Beynen P, Motta PJ (2009) Movement patterns and water quality preferences of juvenile bull sharks (Carcharhinus leucas) in a Florida estuary. Environ Biol Fishes 84:361-373

Peterson BJ, Fry B (1987) Stable isotopes in ecosystem studies. Annu Rev Ecol Syst 18:293-320

Peverell SC, McPherson GR, Garrett RN, Gribble NA (2006) New records of the river shark Glyphis (Carcharhinidae) reported from CapeYork Peninsula, northern Australia. Zootaxa 1233:53-68

Portnoy DS, McDowell JR, Heist EJ, Musickn JA, Graves JE (2010) World phylogeography and male-mediated gene 
flow in the sandbar shark, Carcharhinus plumbeus. Mol Ecol 19:1994-2010

Post DM (2002) Using stable isotopes to estimate trophic position: models, methods, and assumptions. Ecology 83: 703-718

Pyke GH (1984) Optimal foraging theory - a critical review. Annu Rev Ecol Syst 15:523-575

R Development Core Team (2011) R: A Language and Environment for Statistical Computing. http://cran.rproject.org/

Salini JP, Blaber SJM, Brewer DT (1992) Diets of sharks from estuaries and adjacent waters of the north-eastern Gulf of Carpentaria, Australia. Mar Freshw Res 43:87-96

Salini J, Pillians R, Ovenden J, Buckworth R, Gribble N, McAuley RB, Stevens JD (2007) Northern Australia sharks and rays: the sustainability of target and bycatch species, phase 2. CSIRO Marine and Atmospheric Research, Cleveland

Simpfendorfer CA, Goodreid AB, McAuley RB (2001) Size, sex and geographic variation in the diet of the tiger shark, Galeocerdo cuvier, from Western Australian waters. Environ Biol Fishes 61:37-46

Simpfendorfer CA, Freitas GG, Wiley TR, Heupel MR (2005) Distribution and habitat partitioning of immature bull sharks (Carcharhinus leucas) in a southwest Florida estuary. Estuaries 28:78-85

Speed CW, Meekan MG, Field IC, McMahon CR, Abrantes K, Bradshaw CJA (2012) Trophic eology of reef sharks determined using stable isotopes and telemetry. Coral Reefs 31:357-367

Stevens JD (2002) A review of elasmobranch fisheries. In: Fowler J, Reed TM, Dipper FA (eds) Proc Int Seminar and Workshop, Occasional Papers of the IUCN Species Survival Commision. IUCN, Sabah, p 122-125

Stevens JD, McLoughlin KL (1991) Distribution, size, sex composition, reproductive biology and diet of sharks from northern Australia. Mar Freshw Res 42:151-199

Stevens JD, Bonfil R, Dulvy NK, Walker TA (2000) The effects of fishing on sharks, rays, and chimaeras (chondrichthyans), and the implications for marine ecosystems. ICES J Mar Sci 57:476-494

Editorial responsibility: Paolo Casale, Rome, Italy
Stevens JD, Pillans RD, Salini J (2005) Conservation assessment of Glyphis sp. A (speartooth shark), Glyphis sp. C (northern river shark), Pristis microdon (freshwater sawfish) and Pristis zijsron (green sawfish). CSIRO Marine Research, Hobart

Taniuchi T, Shimizu M, Sano M, Baba O, Last PR (1991) Descriptions of freshwater elasmobranchs collected from three rivers in northern Australia. In: Shimizu M, Taniuchi $\mathrm{T}$ (eds) Studies on elasmobranchs collected from seven river systems in northern Australia and Papua New Guinea. Nature and Culture 3:11-26

Thorburn D, Rowland AJ (2008) Juvenile bull sharks Carcharhinus leucas (Valenciennes, 1839) in northern Australian Rivers. The Beagle 24:79-86

Tillett BJ, Meekan MG, Field IC, Hua Q, Bradshaw CJA (2011a) Similar life history traits in bull (Carcharhinus leucas) and pig-eye (C. amboinensis) sharks. Mar Freshw Res 62:850-860

Tillett BJ, Meekan MG, Parry D, Munksgaard N, Field IC, Thorburn D, Bradshaw CJA, (2011b) Decoding fingerprints: elemental composition of vertebrae correlates to age-related habitat use in two morphologically similar sharks. Mar Ecol Prog Ser 434:133-142

Tillett BJ, Meekan MG, Field IC, Thorburn D, Ovenden JR (2012) Evidence for reproductive philopatry in the bull shark, Carcharhinus leucas in northern Australia. J Fish Biol 80:2140-2158

> Veríssimo A, Grubbs D, McDowell J, Musick J, Portnoy D (2011) Frequency of multiple paternity in the spiny dogfish Squalus acanthias in the western north Atlantic. J Hered 102:88-93

Werry JM, Lee SY, Otway NM, Hu Y, Sumpton W (2011) A multi-faceted approach for quantifying the estuarine-nearshore transition in the life cycle of the bull shark, Carcharhinus leucas. Mar Freshw Res 62: 1421-1431

> Yeiser BG, Heupel MR, Simpfendorfer CA (2008) Occurrence, home range and movement patterns of juvenile bull (Carcharhinus leucas) and lemon (Negaprion brevirostris) sharks within a Florida estuary. Mar Freshw Res 59:489-501

Submitted: August 23, 2013; Accepted: May 21, 2014 Proofs received from author(s): September 18, 2014 